\title{
КИНЕТИКА ЭКСТРАКЦИИ РЗЭ РАСТВОРАМИ Д2ЭГФК В СТАТИЧНОЙ И ПРОТОЧНОЙ СИТЕМАХ
}

\author{
Кизим Н.Ф., Голубина Е.Н. \\ Новомосковский институт \\ ФГБОУ ВО «Российский химико-технологический университет имени Д.И. Менделеева», \\ Новомосковск, Россия \\ nphk@mail.ru
}

DOI: 10.26902/ASFE-11_160

Для выделения, разделения и концентрирования веществ широкое применение в аналитической химии получила жидкостная экстракция. Экстракция редкоземельных элементов (РЗЭ) растворами ди-(2-этилгексил)фосфорной кислоты (Д2ЭГФК) сопровождается межфазными явлениями, а именно, возникновением и развитием спонтанной поверхностной конвекции (СПК), химическими реакциями, накоплением РЗЭ в динамическом межфазном слое (ДМС), структурообразованием в ДМС, частичным эмульгированием. Межфазные явления оказывают влияние на скорость экстракции РЗЭ.

В настоящем сообщении представлены результаты кинетических исследований экстракции РЗЭ растворами Д2ЭГФК при локальном колебательном воздействии в ДМС и в его отсутствии.

Экстракцию в статичной системе проводили в ячейке конусообразной формы; в проточной системе с ламинарно-текущими жидкостями - в ячейке цилиндрической формы с четырьмя штуцерами для ввода и вывода жидкостей и замкнутыми контурами водной и органической фаз. Как в статичной, так и проточной системах через заданное время опыт прекращали, фазы разделяли и фотоколометрически определяли содержание РЗЭ в водной и, через стадию реэкстракции, в органической фазах. При исследовании влияния локальных механических колебаний на скорость экстракции установливали виброэлемент, приводимый в движение вибратором, питание которого осуществлялось от генератора низкочастотных сигналов. До начала опыта на межфазную поверхность жидкость / воздух устанавливали виброэлемент, приводили его в движение, затем аккуратно по стенке ячейки приливали раствор Д2ЭГФК (в статичной системе) или приводили в движение органическую фазу (в проточной системе). Для оценки влияния внешних факторов на экстракцию при колебательном воздействии использовали коэффициент усиления экстракции $(E)$, определяемый при заданном времени как соотношение концентраций РЗЭ в органической фазе при наличии механических колебаний и при их отсутствии.

Величина $E$ при локальном колебательном воздействии определяется природой извлекаемого элемента, растворителя, частотой и амплитудой колебаний виброэлемента, скоростью движения жидкостей, начальными концентрациями извлекаемого элемента и экстракционного реагента. В статичной системе достигается $4 \div 5$ кратное повышение скорости экстракции, а в проточной системе $2 \div 2,5$ в начальный период времени, т.е. когда интенсивность СПК высока. По мере снижения интенсивности СПК и повышения накопления Р3Э в межфазном слое величина $E$ снижается и достигает до $1,1 \div 1,2$ (статичная система) и 1,9 (проточная система). В проточной системе межфазные образования частично увлекаются в органическую фазу, обновляя межфазную поверхность. При экстракции в проточной системе при наличии колебательного воздействия из-за меньшего накопления РЗЭ в ДМС и более низкой скорости формирования межфазной пленки, экстремальная точка на временной зависимости $E$ менее выражена и смещается в область больших времен. В статичной и проточной системах локальное колебательное воздействие в ДМС препятствует формированию межфазной пленки.

Работа поддержана грантами Российского фонда фундаментальных исследований проект № 19-03-00194 и Правительства Тульской области ДС/160. 